\title{
A small university and knowledge-based development: a case of Northern Iceland
}

\author{
School of Business, \\ University of Iceland, \\ Gimli at Saemundargata, \\ 101 Reykjavik, Iceland \\ E-mail: ire@hi.is
}

Ingi Runar Edvardsson

\begin{abstract}
The aim of this paper is to outline the progress of the University of Akureyri and its effect on regional development in Northern Iceland during the period of 1987-2012. A case study methodology was used, drawing upon historical material, official sources, and interviews. The main findings are that the university has greatly stimulated knowledge-based development in Northern Iceland. It has enhanced regional innovation dynamism by strengthening human, relational, structural and social capital of the area. This paper has drawn attention to diverse positive effects of a small university with regard to regional- and knowledge-based development. As such, it might serve as a catalyst for further research in this area.
\end{abstract}

Keywords: small university; knowledge-based development; KBD; regional innovation dynamism; case study; Northern Iceland.

Reference to this paper should be made as follows: Edvardsson, I.R. (2014) 'A small university and knowledge-based development: a case of Northern Iceland', Int. J. Knowledge-Based Development, Vol. 5, No. 2, pp.131-151.

Biographical notes: Ingi Runar Edvardsson is a Professor at the School of Business, University of Iceland. He received his $\mathrm{PhD}$ in Sociology from the University of Lund, Sweden. His research and publication includes: knowledge and human resource management, outsourcing, regional universities and Nordic labour markets. He has presented his research at several international conferences, including Academy of Management; International Forum on Knowledge Asset Dynamics, Decowe: Development of Competencies in the World of Work and Education, International Labour Process Conference and European Regional Science Association. His articles have appeared in Employee Relations, Journal of Knowledge Management, Knowledge Management Research \& Practice, International Journal of Entrepreneurship and Small Business, International Journal of Knowledge-Based Organizations, and Scandinavian Journal of Education Research. He has also published several book chapters.

This paper is a revised and expanded version of a paper entitled 'The foundation of a university and knowledge-based development in Northern Iceland' presented at the 6th Knowledge Cities World Summit (KCWS-2013), Istanbul, Turkey, 9-12 September 2013. 


\section{Introduction}

\subsection{Background}

In 2013, The World Capital Institute selected Melbourne, Australia as the most admirable knowledge city. Other cities that have been selected by the Institute are Manchester and Singapore (The World Capital Institute, 2013) amongst others. This indicates that big cities and metropolitan areas have been the main focus of those writing about knowledge cities and knowledge-based development (KBD) (see for example Grant and Chuang, 2012; Sarimin and Yigitcanlar, 2012; Searle, 2010; Yigitcanlar et al., 2008). Universities and research institutions have a central role in knowledge-based development. Very little has, however, been written about smaller cities and regional universities in this context, with a few exceptions (Nilsson, 2006; Makkonen, 2012). This paper attempts to address that shortcoming by presenting a case study of a small university in Northern Iceland and its impact on the local economy, culture and regional development.

\subsection{Knowledge-based development}

KBD is a theoretical and technical field which has its roots in knowledge management, intellectual capital and an economic analysis of the knowledge economy (Carrillo, 2007). The basic assumption behind KBD is that knowledge, innovation, and creativity have become central to production and progress (Ergazakis and Metaxiotis, 2011; Lin and Edvinsson, 2012). KBD research has escalated in recent years. There are four major streams of KBD research according to a literature review conducted by Ergazakis and Metaxiotis (2011, p.373):

- concepts, strategies, approaches, frameworks, and methodologies

- KB-urban planning

- practical application

- $\quad$ assessment and metrics.

In this paper, the focus will be on the practical application of KB planning by analysing a particular instance of concrete KBD. More precisely, we will pay special attention to the role of regional universities in enhancing regional innovation dynamism (Schiuma and Lerro, 2008).

\subsection{Regional innovation dynamism}

Goldstein and Glaser (2012, p.158) argue that in the knowledge-based economy "universities have a variety of potential roles for stimulating economic development beyond teaching, research and technology development". Among these is the co-location effect where universities attract scientists and creative people to the area. Universities can also have a governance role by which they can improve the administrative capacity and effectiveness of a region; furthermore, research universities will add to local knowledge assets, as they tend to specialise in knowledge, talent, and expertise which have the potential to solve regional problems. Universities have been signalled out as major actors in developing regional innovation systems (Gunasekrara, 2006). Karlsen (2005) points 
out that universities are generally expected to have a central role in innovation by establishing a network with local actors. Such networks are considered to enhance innovation and value creation in the regions. Various models of regional innovation systems have been suggested. Etzkowitz (2002) has presented the triple helix model where he stresses that universities are central institutions in economic regulations, alongside industry and the state. Titze et al. (2012) present a regional innovation model based on common outputs of universities; that is, publications, patent applications, R\&D collaboration projects and potentials for relations with industrial clusters. Cantú et al. (2012) introduced a knowledge-developmental model based on a research chair strategy (research groups within universities and research institutions). The most comprehensive model is presented by Schiuma and Lerro (2008) under the title 'Knowledge-based capital in building regional innovation capacity’. They interpret regional knowledgebased capital as: “....any regional resource made of or incorporating knowledge which provides an ability to carry out a process or an activity aimed at creating and/or delivering value” [Schiuma and Lerro, (2008), p.124]. They identify four main knowledge asset categories which constitute regional knowledge-based capital:

- human capital

- relational capital

- $\quad$ structural capital

- $\quad$ social capital.

Human capital has been defined in various ways. Kaplan and Norton (2004) define human capital as the availability of skills, talent, and know-how to perform activities, whereas Cantú et al. (2009) see professors and academic staff, as well as students, receiving training and education as the human capital of a region. Titze et al. (2012) classify qualification/training, supervision of students, exchange of personnel, and job mobility under the category of human capital. Schiuma and Lerro (2008) look at human capital as explicit and tacit knowledge characterising the actors (individuals and collective actors) within the region. In this context, they mention brain drain and attraction as fundamental factors affecting regional development in the present knowledge economy. Regional universities counteract brain drain, by decreasing outmigration of young people to university areas, as well as by attracting highly educated staff and creative individuals (Lundmark, 2002; Riepula, 2002; Edvardsson and Gunnarsson, 2002; Nilsson, 2006; Nord, 2002; Weller, 2002).

Relational capital and networking denotes the group of knowledge resources relevant to the relationships characterising a regional system (Schiuma and Lerro, 2008). As already noted, universities can change the governance of the region, thus altering the relational capital and increasing local effectiveness and competence (Goldstein and Glaser, 2012). Universities also tend to enhance the external relational capital of a region. Conferences, student exchanges, guest lecturers and foreign teachers bring international knowledge and ideas to the regions. Moreover, areas where regional universities are located tend to be the subject of research projects and surveys, and these findings are published in international books and journals (Lundmark, 2002; Riepula, 2002; Edvardsson and Gunnarsson, 2002; Nilsson, 2006; Weller, 2002).

Structural capital includes intellectual assets owned by stakeholders, and technological infrastructure according to Schiuma and Lerro (2008). Research institutions 
could be added here, as they augment regional structural capital. Research institutes are founded in direct connection with universities. In turn, these institutions transfer important innovations and discoveries into local firms (Lundmark, 2002; Riepula, 2002; Edvardsson and Gunnarsson, 2002; Nilsson, 2006; Weller, 2002). Universities tend to strengthen the infrastructure of neighbouring districts by ensuring good communications by road and air and sophisticated computer and information systems, since equipment for conducting teleconferences is increasingly used in teaching and development work etc. (Edvardsson and Gunnarsson, 2002). Within KBD research much emphasis has been placed on ICT technologies and IT systems in this respect (Ergazakis and Metaxiotis, 2011).

Social capital is related to the soft infrastructure and includes numerous items, such as values, culture, behaviours, networking, identity etc (Schiuma and Lerro, 2008). Social capital is important in building trust that can enhance sharing of knowledge and it can decrease transaction cost. It also strengthens ties and social cohesion that is positively related to the ease of knowledge transfer (Wang and Noe, 2010). All this strengthens regional cooperation and stimulates innovation.

Finally, the economic impacts of universities are varied and significant, such as providing work for people with a university education; a wide-ranging multiplication effect in the economic sphere; investments in buildings; tax income; student and staff consumption; broadening the labour market as they educate people for a variety of careers. In addition, spin-off firms, such as biotechnological and software companies, tend to set up in close proximity to universities (Brulin, 1998; Karlsen, 2005). Universities also create positive economic environment by attracting scientists, engineers and entrepreneurs; thus encouraging highly creative and educated people, to settle down in specific regions, as already mentioned (Goldstein and Glaser, 2012).

\subsection{Objective of the paper}

The purpose of this paper is to outline the progress of the University of Akureyri (UNAK) and its effect on regional development in Northern Iceland during the period of 1987-2012. The main research task is to analyse the influence of UNAK on regional innovation dynamism in Northern Iceland. This involves investigating:

1 how a small university altered the human capital of the area

2 how it changed the relational capital

3 strengthened the structural capital

4 amended the social capital in the Akureyri area.

Finally, we ask how UNAK influenced regional development in the area.

\section{Methodology}

The paper is based on a case study methodology. The rationale for choosing a case study method is that it contains rich detail of a specific context, which can illustrate and enrich our understanding of a particular phenomenon. The method helps us to understand dynamics within a single setting (Eisenhardt, 1989). The selection of UNAK is based on 
a theoretical sample strategy (Burgess, 1984; Eisenhardt, 1989). The university is also a suitable illustration of the dynamics and development of such higher educational institutions, and how they can shape KBD in a regional context. As such it is an instrumental case study (Stake, 1995). The analysis is based on a within-case analysis (Eisenhardt, 1989) where a variety of sources were examined, such as data on student and staff numbers from the university register; official statistics on population growth and industrial development and a recently published history of the university (Gudmundsson, 2012). Furthermore, my experience as a professor at the university in the period of 1997-2011 has helped my analytical reflection. Hence, the data is of both a qualitative and quantitative nature.

Seventeen structured interviews were also conducted. Nine politicians and local municipality officials, as well as a former rector of the university were asked four questions (about the university's impact on Akureyri; regional growth; influence on firms and industry, and on media, infrastructure and culture in the local area). In addition, eight representatives of private firms and governmental organisations, such as the regional hospital and the unemployment agency, were interviewed and asked five questions (whether they have hired staff from UNAK; whether their employees have attended continuing education at UNAK; whether UNAK's research institutes have conducted research for the firms; and how they assess the general impact of UNAK on their firms and Akureyri). The selection criteria for the interviews were convenience and theoretical sampling (Burgess, 1984); politicians and local municipal officials who have lived in the area for decades were selected, and only representatives for knowledge-intensive companies were interviewed as the university's influence is likely to be strongly felt in such companies. The interviews were both conducted face to face or via telephone, and lasted from 9 to 47 minutes.

\section{The University of Akureyri}

\subsection{Akureyri and industrial restructuring}

UNAK is located in Akureyri, the largest town in Iceland outside the capital area (see Figure 1). The town, which is also a regional centre, is in the North-Eastern part of the country and has about 18,000 inhabitants. In Akureyri there are two radio stations (one with national coverage, one local), two local weekly papers, one local TV-station, a theatre, a provincial hospital and various governmental services, such as a tax office, a post office, etc. A domestic airport is located near Akureyri with up to five flights a day to Reykjavik.

Akureyri was a leading manufacturing town in Iceland for the majority of the 20th century, with large industrial companies such as a cannery, a fish processing plant, a herring plant and a large factory that manufactured shoes and clothes out of wool and pelts. Other industrial companies included a dairy, a meat-processing firm, a chocolate-factory, a brewery, a plastics manufacturer, a soft drink factory and a printing house. There was also a large shipyard which provided numerous jobs in shipbuilding and repairs. By the middle of the 1980s, many of the local industries were in severe trouble and several industrial establishments went bankrupt. This was due to the collapse of the Soviet Union, an important export market, and also connected with decreased tariff protection as a result of EFTA regulations. In the period of closure of industrial factories 
in Akureyri in the 1980s, hundreds of workers were laid off, and UNAK was founded (Edvardsson and Gunnarsson, 2002). The current managing director of the regional hospital in Akureyri is symbolic of those changes. He used to work for an industrial company which ceased operations and he says: "the town was rapidly transformed from an industrial town to a knowledge community. Employment in industry shrunk and at the same time the university appeared on the scene and became a new mainstay in the community. It is thanks to UNAK that Akureyri has many services to offer which otherwise would probably not have come into existence.”

Figure 1 Map of Iceland (see online version for colours)

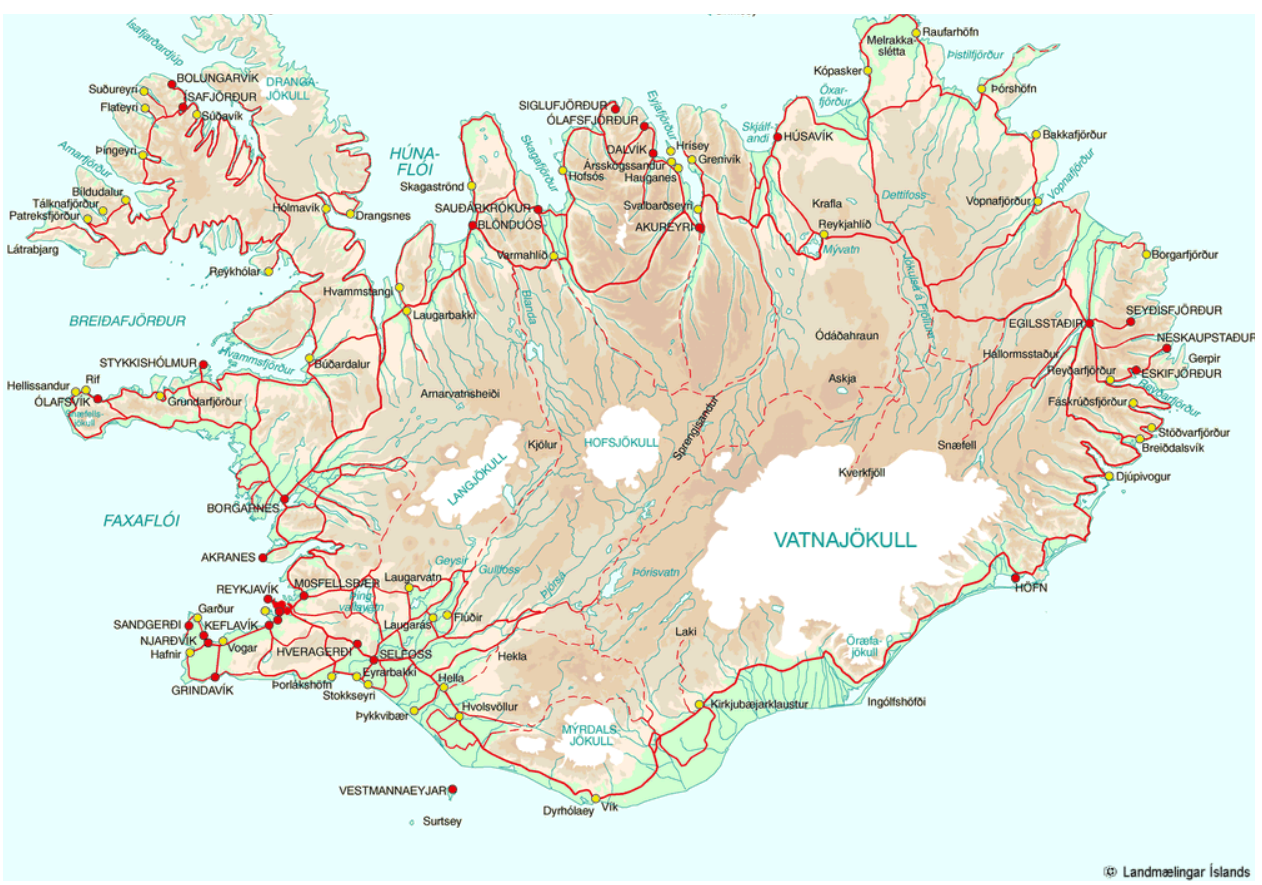

A former rector of the university pointed out that there was a population decline in Akureyri when UNAK was founded and that a positive change soon followed, to a large extent due to the operation of the university. Similar attitudes towards the positive influence of UNAK for the development of the Akureyri area were expressed by the majority of people who were interviewed. In their opinion, the university arrived just at the right moment to stimulate the positive development of Akureyri and the neighbouring regions.

\subsection{The University of Akureyri}

UNAK was the third university to be founded in Iceland. The other two were in Reykjavik, the centre of higher education in Iceland. Before UNAK was founded, every student from rural areas had to move to Reykjavik in order to receive higher education. Still today, Reykjavik occupies a dominating position within the university system, with about $86 \%$ of students living and studying in the capital area (Statistics Iceland, 2013a). 
UNAK became operational on 5 September 1987 with permission from the Ministry of Education and Culture, although the bill of law relating to the University's operation was not passed by the National Assembly until 27 April 1988. The opinions expressed by members of parliament during the debate clearly indicate that the main weight behind the decision to establish the university was a strong emphasis on regional development. The aim was to try to motivate young people to settle down in the area and to attend courses in short programmes of study of a practical nature, which would be seen as relevant right from the foundation of the university. Originally, the stated purpose of the UNAK was to provide its students with an education which qualified them for various tasks in industry and positions of responsibility within the community, or enabled them to pursue further study at university level. Research under the auspices of the university was not included in its original aims. This, however, emerged later, in an Act of the National Assembly on 18 May 1992 (Gudmundsson, 2012).

The UNAK has grown and prospered from its beginnings. This applies equally to the courses on offer, the number of students and the funding and staff. During its first semesters, the university only offered a programme in nursing (four years) and industrial management (two years). A four year programme in fisheries science commenced on 4 January 1990 and a teacher education faculty was established in autumn 1993 (B.Ed. level). The next development was the establishment of the Faculty of Information Science in 2001, and finally the founding of the Faculty of Social Sciences, Law and Humanities in 2003. The university has diversified in recent years, and the schools within the University and their study programmes are presented in Table 1. Most of the programmes are at undergraduate and master's levels, which are also provided in distance education (Gudmundsson, 2012).

Table 1 Schools and study programmes within the UNAK

\begin{tabular}{lc}
\hline Schools at the university & Number of students in 2013 \\
\hline School of health sciences & 438 \\
Nursing & \\
Occupational therapy & 450 \\
School of business and sciences & \\
Business administration & 680 \\
Biotechnology & \\
Fisheries studies & \\
School of humanities and social science & \\
Social sciences & \\
Modern studies & \\
Psychology & \\
Education & \\
Mass media & \\
Law & \\
Polar law
\end{tabular}

Source: The University of Akureyri (2014) 
Although the university has generally been successful in its operation, the economic crisis and insufficient student enrolment were the main reasons for the closure of the Faculty of Information Science in 2008.

Figure 2 shows the number of permanent staff at the university, which has grown from five individuals in 1987 to 173 in 2012. When part-time teachers are included, the numbers are far higher.

Figure 2 Number of permanent staff of the UNAK (see online version for colours)

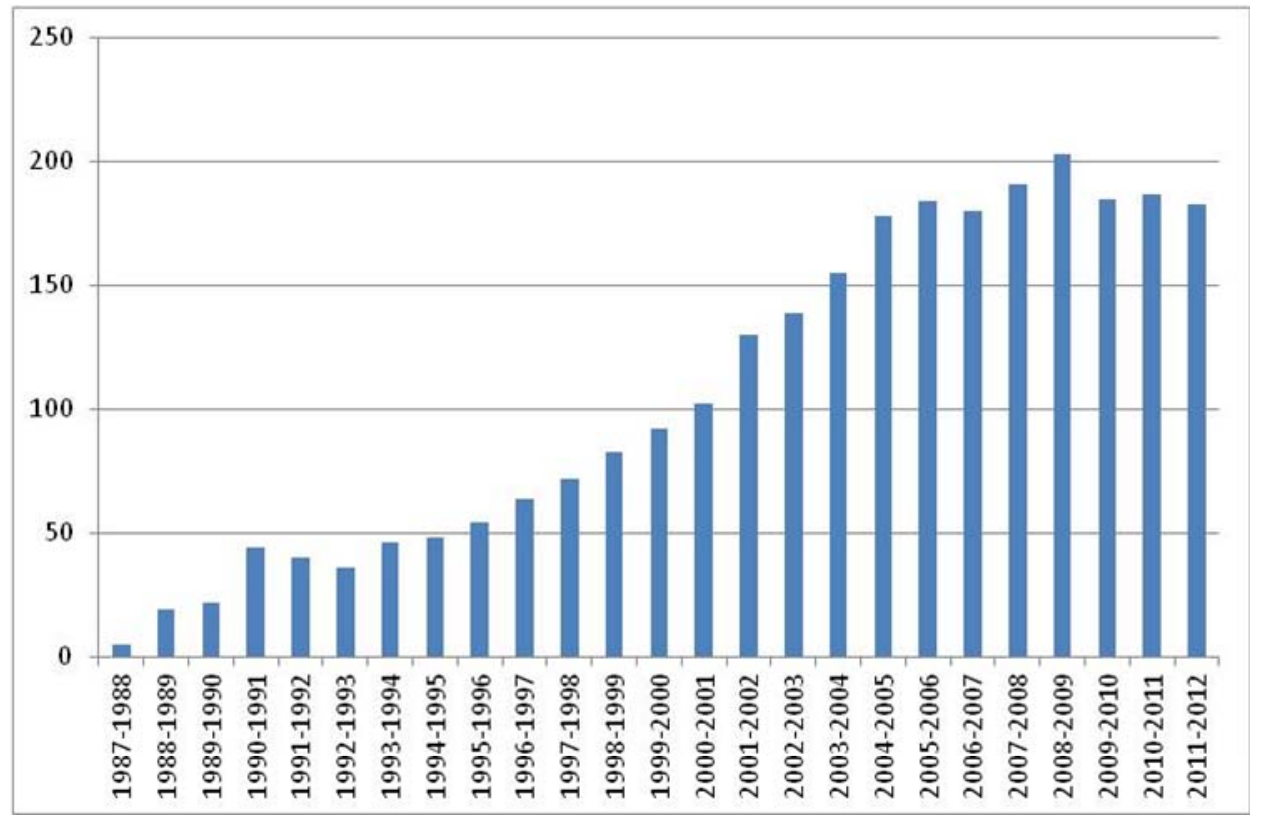

\subsection{Human capital}

A major role of the UNAK, and one of the main reasons for establishing it, is to provide enhanced access to a university education in Northern Iceland. The local people and government alike argued for the establishment of the university on both access and regional development grounds.

Low participation rates in higher education in rural areas are a reflection of many financial, educational and psychological barriers. The financial barrier is probably the most important; as it is prohibitively expensive to send an individual to university for a year, more often than not an amount well out of reach for most families. Another set of barriers to access for rural students is that they, typically, do not perform as well in the sciences and languages as students from larger urban areas. This is partly due to fewer physical resources being available, partly because of a shortage of appropriately qualified teachers and partly the consequence of a lesser focus in rural schools on those subjects required for university entry, since family and peer pressure tends to be directed towards the world of practical activities at a relatively early stage. Among the significant psychological barriers for rural students is the widespread belief that a university 
education is not needed to acquire a high-paying job. Another psychological barrier is the adjustment to moving away from home, adapting to a city and all its attractions and assimilating to an independent lifestyle (Weller, 1998).

As can be seen from Figure 3, there has been constant growth in student numbers throughout the history of the UNAK, apart from the years 2006-2008. Out of the student population, $71 \%$ are females, and $29 \%$ are males. This is due to the fact that primary teaching and nursing are dominated by women and the faculties of Education and Health Science, which prepare students for those two professions, have attracted large numbers of women students. On average, campus students are about 30 years of age, while distance education students average 38 years (Gudmundsson, 2012). The director of Símey (Eyjafjörður centre of continuing education) says in relation to students at Akureyri University:

\begin{abstract}
"Some people settle down here because of the university. More women attend the academic programmes, since the studies are more oriented towards professions favoured by women. Increased emphasis on disciplines more suited to male interests should be considered. There are all manner of loudly voiced suggestions that UNAK should do this and that, for example initiate new paths of study; this, however, cannot be achieved for economic reasons. Perhaps cooperation could be established with universities or technical colleges abroad, for example in Denmark where the study of technical subjects is popular among Icelandic students, some of whom come from Akureyri Comprehensive College (VMA).”
\end{abstract}

Figure 3 Number of students at the UNAK (see online version for colours)

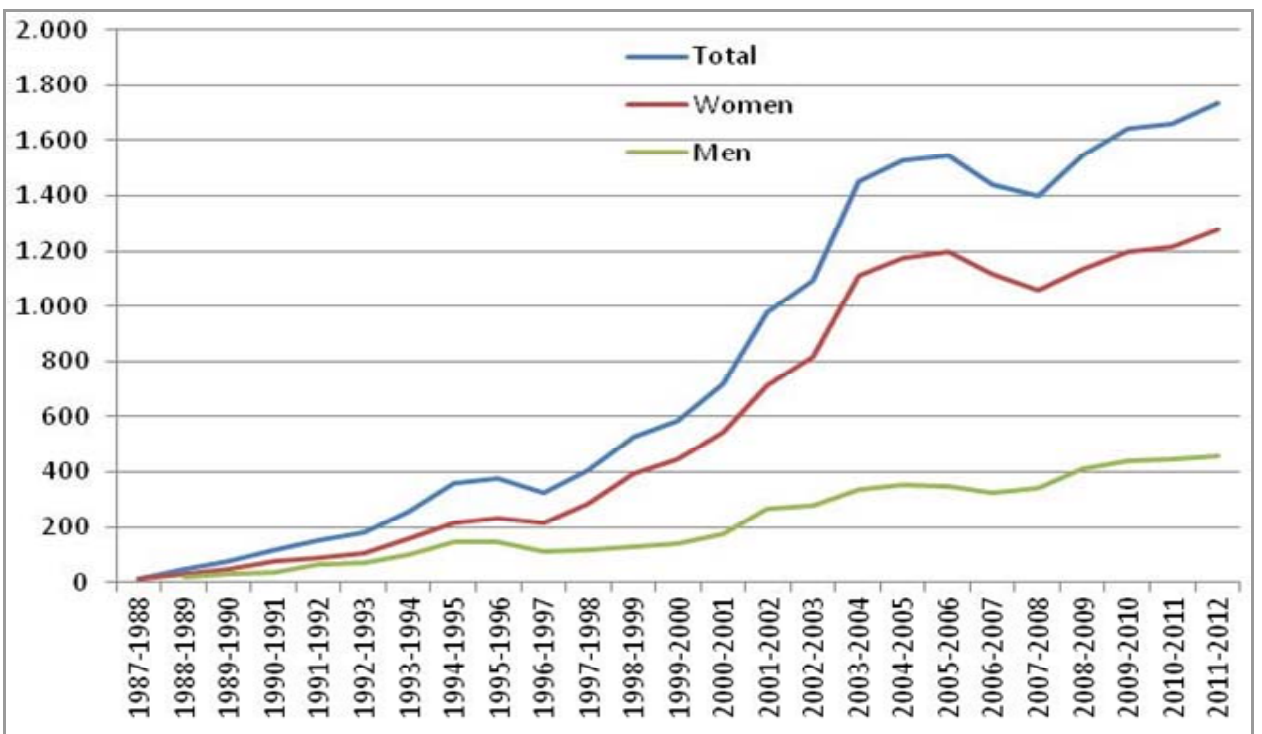

The university has strongly influenced employment in the local economy (Akureyri has 17,966 inhabitants). In direct terms, it employs about 173 university educated staff on a permanent basis. Most of the academic staff has a $\mathrm{PhD}$; whereas a minimum requirement 
is a master's degree. Moreover, the university has provided schools, hospitals and companies within the local economy with urgently needed educated personnel. The hiring of university graduates has become far easier in the Eyjafjördur area since the founding of UNAK in 1987. On this matter, a former Minister of Education and Culture states:

\begin{abstract}
"From the beginning it was a matter of priority that the university should be developed in cooperation with the strongest research and science institutes already on location. That is why UNAK established a Faculty of Education and a Faculty of Health Sciences, since these programmes both stimulated student recruitment and provided a solid connection with the local economy. Research has shown that students from the UNAK are more likely to want to settle down and work in the outlying regions than graduates from other universities. This particularly applies to the Faculty of Education. The ratio of qualified teachers in Akureyri preschools is significantly higher than in the Reykjavík area, a fact which amply demonstrates the impact of Akureyri University.”
\end{abstract}

The director of Education of Akureyri Municipality also refers to the importance of UNAK for local education when he says: “advice from the University’s Centre of School Development is of significant practical value. Akureyri Municipality pays 2.5 full time equivalents per annum and is, in return, granted ready access to a comprehensive group of experts in the field of education. The Faculty of Education is crucial to Akureyri as a school town.”

The managing director of Akureyri Hospital strikes a similar chord when he states that a chronic lack of nursing staff has been brought to an end by the university. The hospital has employed numerous nursing staff, occupational therapists, business and computer science graduates who have been trained and educated at the UNAK. He also mentions links with UNAK's School of Health Sciences and the Research Centre for Health Science where hospital staff are earning academic degrees and some of those work part time as members of the university's academic staff.

Another example of UNAK's human capital impact is manifested by the growing presence of professional firms, such as KPMG, Deloitte and PriceWaterhouseCoopers, which have increased their operation in the area; while others, for example ICT companies, have opened up operations in Akureyri. Most of them have hired computer scientists, business studies graduates, and social scientists. In some cases specialists in these firms teach part-time at the university and that enhances their competences. Table 2 shows a summary of interviews conducted for the purpose of this study with representatives of the knowledge-intensive firms.

The university has transformed the supply of labour with a university degree in the region. Almost $50 \%$ of the students who graduated from the UNAK in nursing and management settled in the Akureyri area (Edvardsson, 2001). This pattern contributed to a significant rise in the proportion of local people with an academic education. Since 1988, there has been a vast sea-change in education among the population of Iceland, and UNAK has meant that Akureyri has followed the national average in this respect (see Table 3), which unfortunately is not the case for many areas outside the capital region in Iceland. 
Table 2 Summary from interviews with managers of knowledge-intensive firms in Akureyri

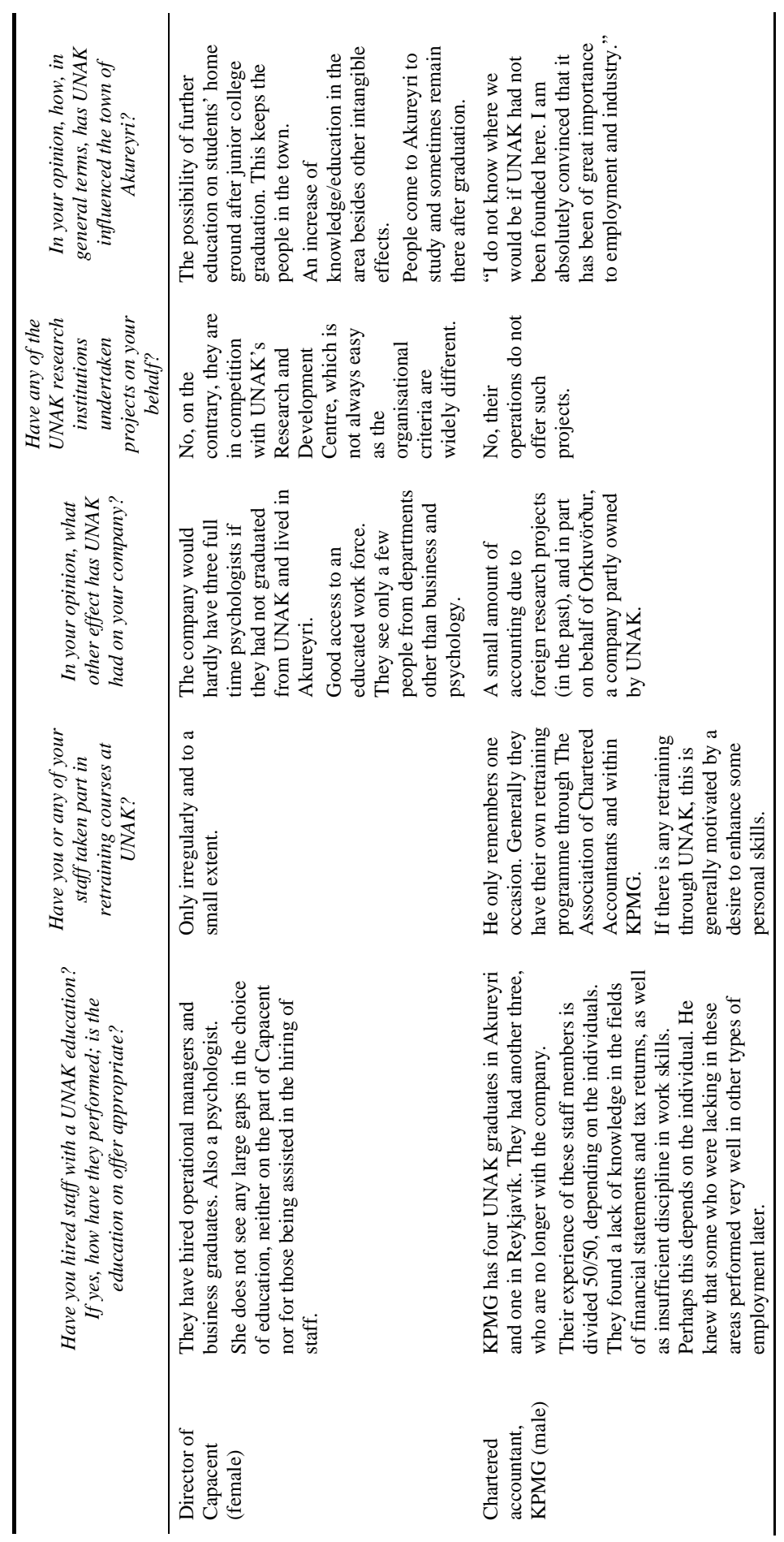


Table 2 Summary from interviews with managers of knowledge-intensive firms in Akureyri (continued)

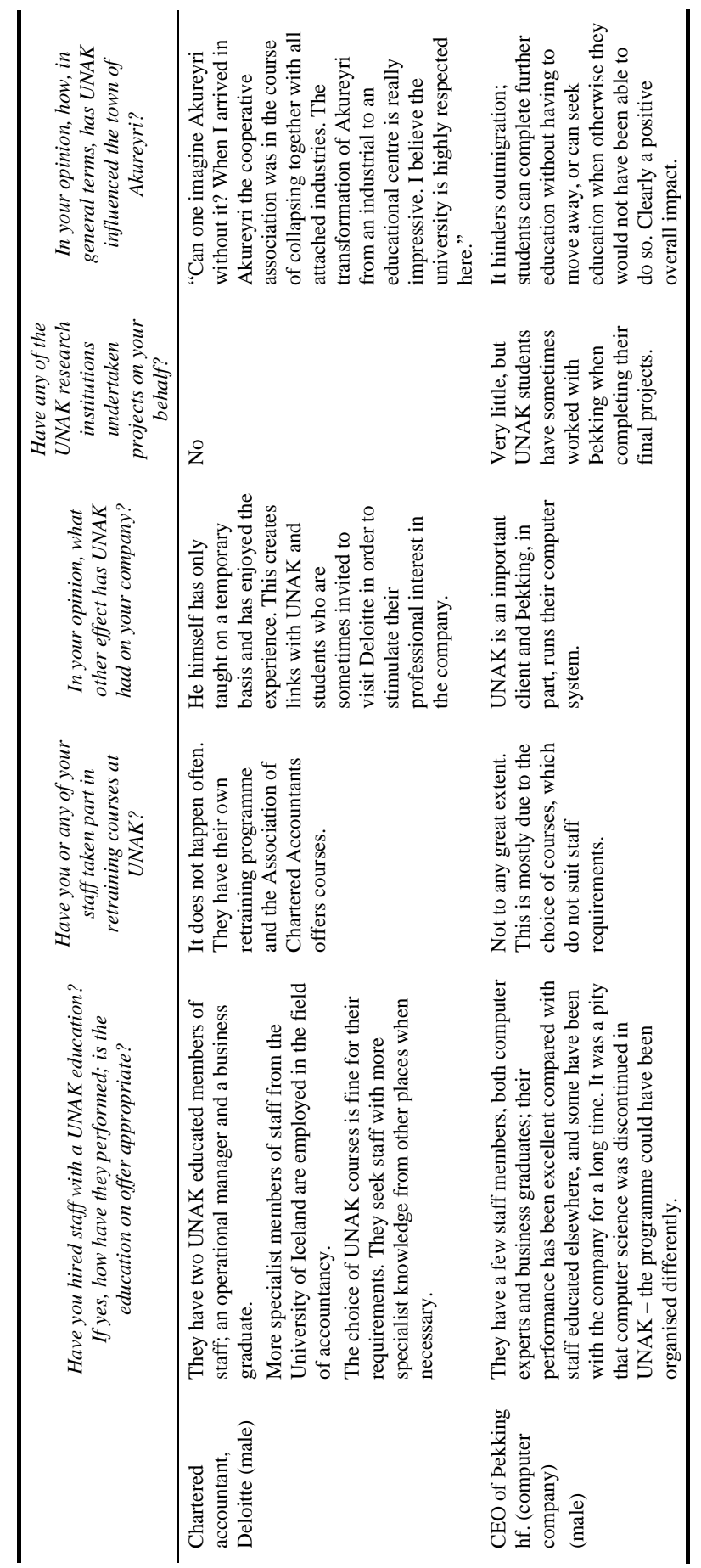


Table 3 Level of education among the population of Akureyri and the national average from 1996-2012, given in percentages

\begin{tabular}{lccccc}
\hline & \multicolumn{2}{c}{$1996-1998$} & & \multicolumn{2}{c}{$2009-2012$} \\
\cline { 2 - 3 } \cline { 5 - 6 } \cline { 5 - 6 } & Akureyri & National average & & Akureyri & National average \\
\hline Primary education & 35.3 & 35.4 & & 36.6 & 28.8 \\
Secondary education & 51.5 & 51.4 & & 37.8 & 39.8 \\
Higher education & 13.2 & 13.2 & & 25.6 & 31.4 \\
Total & 100.0 & 100.0 & & 100.0 & 100.0 \\
\hline
\end{tabular}

Source: The Social Science Institute of the University of Iceland, 1999 and 2013: data from the national surveys 1991-1998 and 2009-2012 ${ }^{1}$

\subsection{Structural capital}

One impact of universities and higher education institutions towards structural capital is their significant investment in computers, distance-learning devices and communications, thereby enhancing the infrastructure of their local economy. This has indeed happened in the case of UNAK. The University has also strengthened the operation of domestic flights to Reykjavik. A former rector of UNAK explains:
"UNAK helped the development and distribution of optical fibre around Iceland with its participation in the RH-network, thus bringing forward the laying of optical fibre across Iceland over the Sprengisandur highland in 1995-96. Distance teaching also made heavy demand on capacity and consequently the Institute of Regional Development set up the so-called Regional Bridge (Byggðabrú) for the benefit of distance education. UNAK makes significant use of air travel between Akureyri and Reykjavik thus strengthening this mode of transport.”

The former rector also pointed out that new roads were built in Akureyri because of the new university campus area that was developed around 2000 and has had significant impact on transport within Akureyri.

The links between the UNAK and industry are strengthened through various cooperative ventures with industry research institutions. This is evident in the four contracts the University has concluded with the Marine Research Institute (Hafrannsóknarstofnun), Innovation Centre Iceland (Nýsköpunarmiðstöð Íslands), the Icelandic Fisheries Laboratories (Rannsóknastofnun fiskiðnaðarins) and the Agricultural Research Institute (Rannsóknastofnun landbúnaðarins). The contracts involve cooperation in teaching and research, sharing of facilities and the co-hiring of specialists, who then have a teaching obligation to the university. Employees hired under the terms of these cooperative contracts have the same rights and obligations within UNAK as other members of academic staff, such as attending faculty meetings and sitting on committees, as well as having the same rights and opportunities to receive research grants and sabbaticals. Cooperation with industry research institutes is crucial, because this enables the university to gain access to existing research and its results, without having to establish the necessary facilities and staff at a great cost. The industrial research facilities also possess vast experience in relationships with industry and commerce. It can be of particular benefit to a young university, in a number of circumstances, to arrange its 
dealings with industry and commerce through such experienced partners as the industry research institutes undoubtedly are. It should be mentioned, furthermore, that the research institutes have a number of international connections which benefit the university (Edvardsson and Gunnarsson, 2002).

The former rector of UNAK refers to a particular example of good cooperation between industry and research at the university where he says: "We could mention energy and marine biotechnology.... where we have worked with companies in the field. Research [by one of the professors] has led to the foundation of the company BioPol in Skagaströnd which has eight staff members."

The UNAK's Research and Development Centre has been at the forefront of strengthening the university's links with industry and commerce. The centre's experts have worked in a service and consulting capacity for various companies and institutions with considerable success. In recent years, more research institutions have been established such as FMSI - The Icelandic Tourism Research Centre; HHA - The Institute of Health Science Research, UNAK; the School Development Centre of UNAK's Faculty of Education and the Fisheries Centre. All these institutions were founded in collaboration with other bodies, such as a hospital, other universities, the government and so on. Other initiatives, such as the Vilhjalmur Stefansson Arctic Institute, founded in 1998, have been affiliated to the university (Gudmundsson, 2012).

Arctic issues have been in focus at UNAK for some time in relation to the Stefansson Arctic Institute, Northern Research Forum and the University of the Arctic. The Arctic Council's offices of Protection of Arctic Marine Environment (PAME) and the Conservation of Arctic Fauna and Flora (CAFF) are located in the university area in Akureyri. "The Caff and PAME institutes at Borgir significantly strengthen the research operations of the UNAK in Arctic regions. Innovations such as Arctic Portal which offer internet services for companies and institutions serve as examples of developments made possible through the impact of the university. Arctic Services, a cluster of companies offering a variety of services have also sprung out of the environment cultivated by the university.” (A former Minister of Education and Culture).

\subsection{Relational capital}

Universities play a central role in establishing networks with local actors. We have already seen how UNAK has enriched the relational capital of the area by networking with the municipality and local firms by means of education and knowledge transfer. In many cases the university has provided services that would otherwise not be available in the area, and it has established diverse networks. The first signs of regional governance led by the university have also appeared. One strong case is the Eyjafjördur regional cluster project (Vaxtarsamningur Eyjafjarðar - Sigurgeirsdottir, 2008), where the rector of UNAK had a leading role in the period 2004-2007. The aim of the regional cluster was to bring together local firms, the university, governmental bodies and other important actors. The rector has also had moral authority and political standing in Iceland regarding Arctic issues.

Another strong case of relational capital enhancement is the relationships with regions outside Northern Iceland, especially international contacts. The UNAK has acted as a catalyst for international influences such as international conferences, the appointments of academic staff and visiting scholars from abroad as well as student 
exchange programmes (Erasmus). In 2012, for instance, nine conferences were organised by UNAK's staff members, whereof three with international scholars participating. The UNAK Bibliography also reveals that in 2012 UNAK staff published 71 articles in peerreviewed journals, thereof 50 articles in ISI Thompson Reuter indexed journals. Two books were published and 40 book chapters and chapters appeared in conference proceedings; 44 scholarly reports and opinions were also published. Probably the most telling international impact of the University is that the northern region has come to play an increasing role in global research and publication. The active participation of UNAK in arctic cooperative ventures such as Arctic Portal has enhanced the international visibility of the university.

\subsection{Social capital}

Social capital is related to soft infrastructure such as values, culture, identity etc. Social capital is important in building the trust and social cohesion needed to stimulate regional innovation (Schiuma and Lerro, 2008; Wang and Noe, 2010). Almost all those who were interviewed mention the positive regional impact of the UNAK. A former Minister of Finance who has been in the Icelandic parliament from 1987 says in this context: "The appreciation and perception of one's own home region becomes more positive... The local identity is strengthened, provided the operation is a success. Contributes to residential stability since UNAK students do not leave the area during their studies and are more likely to go on to find work there. This impact extends far beyond the region because of distance teaching in various parts of the country." This contributes to social cohesion and trust. Universities are also institutions that people trust well, even after the financial crisis as a result of which institutional trust has decreased considerably (Vísir, 2013).

The University has strongly affected cultural life in Northern Iceland. The first point to be made in this connection is the fact that its staff and students are discerning and demanding customers as far as the 'cultural market' is concerned, being keen patrons of the theatre, concerts and other cultural events. The students frequent cinemas, pubs, cafés and other places of entertainment, thereby strengthening the financial basis of such locales. In this regard the Mayor of Dalvík says: "The University must influence cultural consumption, for example in Hof and Berg where university people are conspicuous at cultural events. This also applies to bookshops, restaurants, cafés and much else which relates to a high proportion of young people. There are such a lot of activities which could not prosper without the university.” The former rector, furthermore, mentioned that exhibitions are held regularly within the university; thus conference guests frequently go to see exhibitions in Akureyri and enhance the cultural life of the area. Cultural production can increase the creativity of the region.

The UNAK has had a positive image in the town and has helped to enhance a confident and independent outlook among the local inhabitants. This was mentioned by almost all those who were interviewed. The mayor of Akureyri says the town's image has been improved because of the advent of the university and he also mentioned that thanks to the university the town was significantly better known abroad. Both the general public and the administrative sector fully realise that universities are to be regarded as symbols of progress and innovation. This positive attitude also applies to the national government in Reykjavík, who have demonstrated that they respect the value of the university and 
support its operations. It is fully understood on the political scene that the university plays a vital part in regional development and the creation of suitable employment opportunities for young scientists and specialised professionals. Media coverage related to UNAK was often mentioned and seen as relevant to the image of the area. Media studies are taught at the university. The director of Akureyrarstofa makes the following comment in this regard:

\begin{abstract}
"Due to the impact of the university, Akureyri's media image has changed. It is to the university, for example, that opinions are sought with regard to contentious issues. The news from here is different because of the university, more dynamic in character and dealing with matters of dispute. Such news gains more prominence than 'attractive' news from other, otherwise, similar locations. This makes the town exciting, for example for those who might want to settle there (again). Monotonous media coverage is not helpful to any location.”
\end{abstract}

Next we turn to regional growth.

\title{
3.7 Regional growth
}

The population of Akureyri has increased by nearly 29\% since 1988, primarily because of high natural population growth (see Table 4). The demographic growth of Akureyri is far higher than for the region as a whole as is demonstrated by the fact that the town's population is expanding in relation to the region. UNAK is one of the reasons for such expansion.

Table 4 Democratic development in Akureyri and the north-east area 1988-2012

\begin{tabular}{lcclccc}
\hline & \multicolumn{2}{c}{ Akureyri } & & \multicolumn{2}{c}{ North-east area } \\
\cline { 2 - 3 } \cline { 5 - 6 } & 1988 & 2012 & & 1988 & 2012 \\
\hline Population (thousands) & 13.9 & 17.9 & & 26.1 & 28.3 \\
Population change \% & & $28.7 \%$ & & $8.4 \%$ \\
Population in city \% of regional population & & $53.6 \%$ & $63.2 \%$ & & & \\
\hline
\end{tabular}

Source: Statistics Iceland (2013b)

The university has also strengthened various businesses in the area, e.g., printing shops, hotels and restaurants, book stores, computer agencies, travel agencies, airlines etc. by its publications, conferences, investments and influx of specialists.

\section{Small university and KBD}

The main aim of this paper is to analyse in what manner a small university, UNAK, has affected regional innovation dynamism in Northern Iceland. Table 5 presents a summary of the main findings of the UNAK case study. In general, we can say that UNAK has had a major influence on innovation dynamism in Northern Iceland. This will be discussed in detail below. 
Table 5 UNAK’s growth and KBD in Northern Iceland

\begin{tabular}{ll}
\hline Human capital & Providing university studies to students \\
& Providing local business with university educated staff \\
& Training and continuous education for local businesses \\
& Providing employment to academic staff \\
& Raising the educational level in the region \\
& Decreasing brain drain in the area \\
Relational capital & Establishing networks with local actors \\
& A sign of regional governance (cluster project) \\
& Changing external relations of the region by internationalisation (mediating \\
knowledge from abroad) & Enhancing ICT tools and networks, distance-learning devices \\
Structural capital & Research institutions and knowledge transfer \\
Social capital & Stronger self-identity contributes to social cohesion and trust \\
& The university as a trusted institution \\
& Stronger cultural consumption and production \\
& Stronger presence in national media (thereby enhancing the image of the \\
area) & Investments in buildings \\
Student and staff consumption & Diversification of industry \\
Regional growth & Strengthening established businesses \\
Attracting new companies needing university educated staff & Attracting young people to the area \\
Preventing an outflow of young people & Attracting specialists and highly educated people to the area \\
\hline
\end{tabular}

UNAK has affected tacit and explicit knowledge in the area in various ways. Like other regional universities (see Lundmark, 2002; Riepula, 2002; Nilsson, 2006; Weller, 2002) UNAK has provided university education for students, primarily at undergraduate level, and also, to some extent, Master's programmes. This has contributed to strengthening human capital in Northern Iceland and has helped stem brain drain from the area and increased the educational level of the region. This is probably the strongest impact of the university on innovation dynamism. But there are some concerns as well. The majority of study programmes are in social sciences, health sciences and humanities. These programmes attract far more females and cause a gender imbalance at UNAK. To further strengthen the human capital in the area, more emphasis should be placed on technical education and natural sciences in order to attract more males and enhance innovation potential, for example in technological transfer. Some of the interviewees asked for more technical education, and even the education of doctors.

Small universities such as UNAK even seem to have an impact on relational capital, albeit to a significantly smaller degree than applies to human capital developments. UNAK has established networks with local actors, such as firms, the municipality, schools and other entities. This is similar to previous findings (Karlsen, 2005). We even 
note signs of regional governance (Goldstein and Glaser, 2012) in two cases; that is, the establishment of a regional cluster project and the focus on arctic issues. UNAK's strongest impact, however, relates to promotion of international issues in Akureyri and surrounding areas. This is manifested in student exchanges, conferences, international publications and visiting scholars.

UNAK has strengthened structural capital in various ways. First, the university has contributed to the present situation where Akureyri has an advanced ICT network system, good channels of transport and an excellent domestic air service. UNAK's main effect on structural capital comprises the research institutions established at the university campus. However, given that most of the institutions are related to social sciences and health, very few spin-off firms have seen the light of day. And direct technical transfer to local firms has been rare.

UNAK's presence is even felt in stronger social capital, as expressed in a changed image of the area, a sign of progress and promise for the future. This process strengthens the social cohesion and trust essential for knowledge transfer. Cultural production has also increased, as well as cultural consumption which is likely to enhance creativity in the region. Also, the media studies taught at the university make Akureyri more visible in the national media and the debate here is different from that of other areas outside the capital area.

UNAK's presence also has a certain economic influence in the area. This is manifested in investments in buildings; student and staff consumption; diversification of industry; strengthening established businesses and attracting new companies needing university educated staff. Similar effects have been noted at other regional universities (Lundmark, 2002; Riepula, 2002; Nilsson, 2006; Weller, 2002). UNAK's multidimensional impact throughout its operation has contributed to positive regional growth.

It is to be expected that a small university will have more limited influence on regional innovation dynamism than larger research universities where it is hypothesised that the effect on human, relational, structural and social capital will be even greater than in the UNAK case study. It is assumed that this will be felt in far larger student numbers and a more pronounced impact on academic staff (human capital); the stronger governance role of large universities and more technological transfer (relational capital); expanded infrastructure changes, more technical research institutions and spin-offs (structural capital), and even stronger image building, cultural production and media coverage (social capital). All this will result in the more powerful economic impact of large universities. Such an analysis is a task for further research, in which scenario a multiple case study might be seen as an interesting research tool.

\section{Conclusions}

The purpose of this paper was to outline the progress of the UNAK and its effect on regional development in Northern Iceland during the period of 1987-2012. A case study methodology has been used, drawing upon historical material, official sources, and interviews.

The main findings are that the university has greatly stimulated KBD in Northern Iceland. It has enhanced regional innovation dynamism by strengthening human, relational, structural and social capital of the area. 
The development of UNAK, presented in this paper, has shown that even very small universities can enhance KBD. The university has not, however, been able to engender spin-off companies or stimulate radical innovation. Such an impact would appear to be above the potential of mini-universities. This paper has drawn attention to diverse positive effects of a small university with regard to regional- and knowledge-based development. As such, it might well serve as a catalyst for further research in this area.

\section{References}

Brulin, G. (1998) Den tredje uppgiften. Högskola och omgivning i samverkan, SNS förlag \& Arbetslivsinstitutet, Stockholm.

Burgess, R. (1984) In the Field, Geord Allen \& Unwin, London.

Cantú, F.J., Bustani, A., Molina, A. and Moreira, H. (2009) 'A knowledge-based development model: the research chair strategy', Journal of Knowledge Management, Vol. 13, No. 1, pp.154-170.

Carrillo, F.J. (2007) 'The coming of age of knowledge-based development', Journal of Knowledge Management, Vol. 11, No. 5, pp.3-5.

Edvardsson, I.R. (2001) 'University education and residential trends in Iceland', Scandinavian Journal of Educational Research, Vol. 45, No. 3, pp.249-268.

Edvardsson, I.R. and Gunnarsson, T. (2002) 'The role of the UNAK in northern development', in Nord, D.C. and Weller, G.R. (Eds.): Higher Education across the Circumpolar North: A Circle of Learning, pp.63-76, Palgrave Macmillan, New York.

Eisenhardt, K.M. (1989) 'Building theories from case study research', The Academy of Management Review, Vol. 14, No. 4, pp.532-550.

Ergazakis, K. and Metaxiotis, K. (2011) 'The knowledge-based development agenda: a perspective for 2010-2020', VINE: The Journal of Information and Knowledge Management Systems, Vol. 41, No. 3, pp.358-377.

Etzkowitz, H. (2002) 'Incubation of incubators: innovation as a triple helix of university-industry-government networks', Science and Public Policy, Vol. 29, No. 2, pp.115-128.

Goldstein, H.A. and Glaser, K. (2012) 'Research universities as actors in the governance of local and regional development', The Journal of Technology Transfer, Vol. 37, No. 3, pp.158-174.

Grant, K.A. and Chuang, S. (2012) 'An aggregating approach to ranking cities for knowledge-based development', International Journal of Knowledge-Based Development, Vol. 3, No. 1, pp.17-34.

Gudmundsson, B. (Ed.) (2012) Háskólinn á Akureyri 1987-2012, Afmælisrit, Völuspá í samvinnu við Háskólinn á Akureyri, Akureyri [The UNAK 1987-2012I, Anniversary publication, Völuspá in cooperation with the UNAK, Akureyri].

Gunasekara, C. (2006) 'Reframing the role of universities in the development of regional innovation systems', The Journal of Technology Transfer, Vol. 31, No. 1, pp.101-113.

Kaplan, R.S. and Norton, D.P. (2004) 'The strategy map: guide to aligning intangible assets', Strategy and Leadership, Vol. 32, No. 5, pp.10-17.

Karlsen, J. (2005) 'When regional development becomes an institutional responsibility for universities: the need for a discussion about knowledge construction in relation to universities' third role’, AI \& Society, Vol. 19, No. 4., pp.500-510.

Lin, C.Y. and Edvinsson, L. (2012) 'National intellectual capital model and measurement', International Journal of Knowledge-Based Development, Vol. 3, No. 1, pp.58-82.

Lundmark, K. (2002) 'The University of Umeå - The university of Northern Sweden', in Nord, D.C. and Weller, G.R. (Eds.): Higher Education across the Circumpolar North: A Circle of Learning, pp.27-45, Palgrave Macmillan, New York. 
Makkonen, T. (2012) 'Peripheral university region and knowledge-based development: the case of Joensuu', International Journal of Knowledge-Based Development, Vol. 3, No. 3, pp.216-233.

Nilsson, J-E. (Ed.) (2006) The Role of Universities in Regional Innovation Systems - A Nordic Perspective, Copenhagen Business School Press, Copenhagen.

Nord, D.C. (2002) 'The role of universities in northern development: a comparative perspective', in Nord, D.C. and Weller, G.R. (Eds.): Higher Education across the Circumpolar North: A Circle of Learning, pp.175-194, Palgrave Macmillan, New York.

Riepula, E. (2002) 'Universities in Northern Finland', in Nord, D.C. and Weller, G.R. (Eds.): Higher Education across the Circumpolar North: A Circle of Learning, pp.7-26, Palgrave Macmillan, New York.

Sarimin, M. and Yigitcanlar, T. (2012) 'Towards a comprehensive and integrated knowledge-based urban development model: Status quo and directions', International Journal of Knowledge-Based Development, Vol. 3, No. 2, pp.175-192.

Schiuma, G. and Lerro, A. (2008) 'Knowledge-based capital in building regional innovation capacity’, Journal of Knowledge Management, Vol. 12, No. 5, pp.121-135.

Searle, G. (2010) 'Knowledge-based development and industry clustering: spatial embeddedness of Sydney and Melbourne's software industry', International Journal of Knowledge-Based Development, Vol. 1, Nos. 1-2, pp.118-135.

Sigursteinsdottir, H. (2008) Vaxtarsamningur Eyjafjarðar. Mat á skilgreindum páttum á tímabili vaxtarsamningsins (2004-2007)og starfsemi einstakra klasa, Rannsóknar- og próunarmiðstöð Háskólans á Akureyri, Akureyri [Eyjafjörður Growth Agreement: assessment of certain factors and the operation of individual clusters, UNAK Centre of Research and Development].

Stake, R.E. (1995) The Art of Case Study Research, SAGE Publications, Thousands Oaks.

Statistics Iceland (2013a) Registered Students in Universities in Iceland 2011 [online] http://www.hagstofa.is/?PageID=2604\&src=https://rannsokn.hagstofa.is/pxis/Dialog/varval.as p?ma=SKO04100\%26ti=Skr\%E1\%F0ir+nemendur+\%E1+h\%E1sk\%F3la\%2D+og+doktorssti gi+eftir+sk\%F3lum\%2C+tegund+n\%E1ms+og+kyni+2007\%2D2011++\%26path=../Database/ skolamal/hsNemendur/\%26lang=3\%26units=Fj\%F6ldi (accessed 17 October 2013).

Statistics Iceland (2013b) Population by Age and Gender in Municipalities 1998-2013 [online] http://www.hagstofa.is/?PageID=2593\&src=https://rannsokn.hagstofa.is/pxis/Dialog/varval.as p?ma=MAN02005\%26ti=Mannfj\%F6ldi+eftir+kyni\%2C+aldri+og+sveitarf\%E9l\%F6gum+19 98\%2D2013+\%2D+Sveitarf\%E9lagaskipan+1\%2E+jan\%FAar+2013\%26path=../Database/ma nnfjoldi/sveitarfelog/\%26lang=3\%26units=Fj\%F6ldi (accessed 17 October 2013).

Statistics Iceland (2013c) Landshagir [National Demographics] 2012 [online] http://hagstofa.is/lisalib/getfile.aspx?itemid=14350 (accessed 18 October 2013).

The UNAK (2014) Information on Schools and Study Programs and Number of Students [online] http://www.unak.is/um-ha/lykiltolur/nemendafjoldi (accessed 23 February 2014).

The World Capital Institute (2013) Homepage [online] http://www.worldcapitalinstitute.org/ (accessed 15 October 2013).

Titze, M., Schwartz, M. and Brachert, M. (2012) 'A systemic view on knowledge-based development metrics', International Journal of Knowledge-Based Development, Vol. 3, No. 1, pp.35-57.

Vísir (2013) Dessar stofnanir njóta mest trausts [Those institutions enjoy the highest level of trust] [online] http://www.visir.is/thessar-stofnanir-njota-mesta-traustsins/article/2013131029423 (accessed 23 Februar 2014).

Wang, S. and Noe, R.A. (2010) 'Knowledge sharing: a review and directions for future research', Human Resource Management Review, Vol. 20, No. 2, pp.115-131.

Weller, G.R. (1998) 'Universities in Northern Canada', paper presented at the 37th Annual Meeting of the Western Regional Science Association, 18-22 February 1998, Monterey, California.

Weller, G.R. (2002) 'Universities in Northern Canada', in Nord, D.C. and Weller, G.R. (Eds.): Higher Education across the Circumpolar North: A Circle of Learning, pp.100-121, Palgrave Macmillan, New York. 
Yigitcanlar, T., Velibeyoglu, K. and Martinez-Fernandez, C. (2008) 'Rising knowledge cities: the role of urban knowledge precincts', Journal of Knowledge Management, Vol. 12, No. 5, pp.8-20.

\section{Notes}

1 There is no register in Iceland where the education of the population can be divided by individual municipalities. Here survey data from the Social Science Institute of the University of Iceland was combined in order to obtain enough individuals to calculate from. The national average in 2009-2012 is very similar to the national average provided by Statistics Iceland. In 2012, 38\% of the population had primary education, $29 \%$ had secondary education and 33\% had higher education (Statistics Iceland, 2013c). 